\title{
Special Issue: Biochemical and Thermochemical Conversion Processes of Lignocellulosic Biomass Fractionated Streams
}

\author{
Anna Trubetskaya ${ }^{1, *(D)}$ and Leonidas Matsakas ${ }^{2, *(D)}$ \\ 1 Department of Sciences and Engineering, University of Limerick, Castletroy, V94 T9PX Limerick, Ireland \\ 2 Biochemical Process Engineering, Division of Chemical Engineering, Department of Civil, Environmental and \\ Natural Resources Engineering, Luleå University of Technology, 97187 Luleå, Sweden \\ * Correspondence: anna.trubetskaya@ul.ie (A.T.); leonidas.matsakas@ltu.se (L.M.)
}

check for

updates

Citation: Trubetskaya, A.; Matsakas, L. Special Issue: Biochemical and Thermochemical Conversion

Processes of Lignocellulosic Biomass Fractionated Streams. Processes 2021, 9, 969. https://doi.org/10.3390/ pr9060969

Received: 17 May 2021

Accepted: 26 May 2021

Published: 31 May 2021

Publisher's Note: MDPI stays neutral with regard to jurisdictional claims in published maps and institutional affiliations.

Copyright: (c) 2021 by the authors. Licensee MDPI, Basel, Switzerland. This article is an open access article distributed under the terms and conditions of the Creative Commons Attribution (CC BY) license (https:// creativecommons.org/licenses/by/ $4.0 /)$.
Global consumption of materials such as forest resources, fossil fuels, earth metals and minerals are expected to double in the next 30 years, while annual waste production is estimated to increase by approximately $70 \%$ by 2050 [1]. Keeping the resource consumption within planetary boundaries, we strive to minimize the carbon and environmental footprint and concurrently double the waste material use in the coming decades. Preventing food waste from being generated could have a major impact on waste collection systems and on the capacity of bio-waste management facilities worldwide [2]. Therefore, sustainable food waste management is a key part of any green business strategy to convert food waste into green fuels.

Thermochemical and biochemical conversion utilizes biomass and waste in an efficient and sustainable way for a wide variety of applications, such as heat, electricity, biofuels, chemicals and biomaterials. This Special Issue aims to explore the most advanced solutions in biomass and waste pre-treatment techniques. Moreover, we have looked into the woody and herbaceous biomass conversion using thermochemical and biochemical processes. This Special Issue has also considered plant species originating from all around the globe. The production of solid or liquid fuels from low-cost lignocellulosic biomass, i.e., forestry residue, agricultural or pulp waste, very often includes a pre-treatment, followed by enzymatic saccharification of the carbohydrates and/or microbial conversion of the sugars to biofuel [3]. Pre-treatment aims to efficiently separate hemicellulose and lignin from cellulose [4]. Removal of lignin from cellulose is particularly important as lignin has a negative influence on enzymatic saccharification due to the irreversible adsorption of cellulolytic enzymes onto lignin and their inhibition from soluble lignin-derived molecules [5]. Hydrothermal pre-treatment is one of the most common methods to effectively degrade hemicelluloses without using chemicals and increase the biomass porosity [6]. The common challenge of hydrothermal pretreatment is related to the fact that the direct separation of lignin is limited; hence, lignin partly tends to rearrange on the surface of the lignocellulosic biomass, causing an inhibitory effect on the saccharification process $[7,8]$. A recent study has shown that steam explosion is not a suitable pretreatment for acid hydrolysis of hardwood lignocellulosic biomass [9]. This Special Issue provides the experimental results on the organosolv separation of agricultural waste and forestry residues [10]. Organosolv pretreatment is known as an effective method to fractionate biomass into three lignocellulosic compounds, i.e., cellulose, hemicellulose and lignin, by using aqueous-organic solvent mixtures, with high solvent concentration (30-70\%) for temperatures ranging from 100 to $220{ }^{\circ} \mathrm{C}$ in the presence or absence of catalysts [11,12]. Thus, the organosolv process provides high-quality cellulose and lignin [13]. A recent study has demonstrated that using the vanadate-hydrogen peroxide system on acetosolv pine lignin, vanillin and isovanillin can be generated as main products with depolymerization yields of $31 \%$ [14]. In another study, the etherification of both organosolv and Kraft lignin with alkyl halides led to the lignin product with the low glass transition temperature and improved thermal stability 
that can be used as thermoplastic [15]. With regards to the conversion of the cellulose to products via microbial fermentation (such as bio-ethanol), two approaches are commonly used. These involve separate hydrolysis and fermentation (SHF) and simultaneous saccharification and fermentation (SSF), and recently, it was shown that SHF is advantageous for bioethanol production from pretreated Napier grass [16]. Apart from glucose, lignocellulosic biomass has other types of $\mathrm{C} 6$ and $\mathrm{C} 5$ sugars. From the different available sugars, processes that use glucose (or other C6 sugars) are more established compared to processes using C5 sugars (such as xylose). Xylose can serve as a carbon source for the cultivation of oleaginous yeasts aiming to produce microbial lipids that can serve as feedstock for biodiesel production $[17,18]$. A recent study demonstrated the potential of the bioconversion of abundant xylose-containing wastewaters into yeast biomass and lipid with satisfactory productions and conversion yields using various yeasts [19].

Knowledge of the composition of raw and pre-treated products is important to better understand the pre-treatment process as well as further refinement of value-added products. The analysis of pre-treated products is tedious due to the complexity of mixtures containing compounds of low and high polarity, which are not always possible to resolve with conventional techniques [20]. The pyrolysis product, i.e., bio-oil, has its challenges, such as the high-water content, high viscosity, low $\mathrm{pH}$, instability, presence of solids, high oxygen content and low calorific value [21]. However, the comparison of bio-oil properties from pinewood and acacia indicated that the yield of bio-oil can be predicted using standard analysis methods such as elemental analysis and volatile matter characterization. Structural and physicochemical characteristics of five different lignins were elucidated using established analysis methods, i.e., gel permeation chromatography for molecular mass features, quantitative ${ }^{31} \mathrm{P}$ NMR and comparative two-dimensional ${ }^{1} \mathrm{H}_{-}{ }^{13} \mathrm{C}$ HSQC analyses for more detailed structural aspects [10]. The selection of analytical methods depends on the complexity of the pre-treatment products and on the final application of the value-added products within the circular economy.

The circular economy plays a dominant role in tackling the climate crisis by redefining the product value with a focus on both the social and environmental benefits. Circular economy principles and strategies using life cycle assessment can be used for analyses of food systems, storage, transportation, feedstock pretreatment, pollutions, etc. [22]. Life cycle assessment within a circular economy can illustrate how the products can be transformed in a way to reduce greenhouse emissions. Thus, the lignocellulosic composition of biomass has a strong impact on the final thermochemical conversion product, leading to consideration of compositional differences in life cycle assessment [23]. The review article on the life cycle assessment of biochar production and utilization for metallurgical processes has been discussed from industrial perspectives. This Special Issue points at several possibilities to integrate the production of bio-based reductants in ferroalloy industries with bio-refineries to lower the cost and increase the total efficiency. Despite challenges related to energy-efficient charcoal production and formation of air pollutions in classical biochar kilns, the potential of bio-based reductant usage in ferroalloy reduction process was underlined as a sustainable pathway to convert forestry to value-added products in metallurgical industries [24]. In addition, the mechanical durability of biochar slightly increased after heat treatment, whereas coal and semi-coke-based reductants showed a decrease in durability. The results indicate that biochar can be used as an efficient carbon source for electric arc furnaces [25]. Overall, more research has to be carried out to identify potential feedstock mixtures for the optimization of the biochar properties.

A promising pre-treatment route of low-value wood refers to various biorefinery processes developed to produce green chemicals. Forestry residues are an excellent potential source of a plethora of renewable chemicals with applications ranging from the energy field to the chemical industry and the potential to replace fossil resources. Therefore, new pre-treatment concepts for low quality wood processing within the circular economy are required to meet the guidelines, as described in the EU green deal [1]. Extraction, microbial fermentation, pyrolysis and organosolv pre-treatments are some of the main 
biomass processing technologies that can be utilized for the conversion of low-quality wood into value-added products. The upscale of such processes will strongly depend on the development of analytical methods that will allow to appropriately evaluate the end products and allow the correlation with the different stages of the process, which in turn will enable to tune the whole process for high yield production of high-quality green chemicals and materials.

Funding: This research received no external funding.

Conflicts of Interest: The authors declare no conflict of interest.

\section{References}

1. European Commission. Communications from the Commission to the European Parliament, the European Council, The Council, The European Economic and Social Committee and the Committee of the Regions. Eur. Green Deal Rep. 2019, 640, 24.

2. Kalmykova, Y.; Sadagopan, M.; Rosado, L. Circular economy-From review of theories and practices to development of implementation tools. Resour. Conserv. Recyc. 2018, 135, 190-201. [CrossRef]

3. Kalogiannis, K.G.; Matsakas, L.; Aspden, J.; Lappas, A.A.; Rova, U.; Christakopoulos, P. Acid Assisted Organosolv Delignification of Beechwood and Pulp Conversion towards High Concentrated Cellulosic Ethanol via High Gravity Enzymatic Hydrolysis and Fermentation. Energies 2018, 23, 1647. [CrossRef] [PubMed]

4. Zhao, X.; Cheng, K.; Liu, D. Organosolv pretreatment of lignocellulosic biomass for enzymatic hydrolysis. Appl. Microbiol. Biotechnol. 2009, 82, 815-827. [CrossRef]

5. Matsakas, L.; Nitsos, C.; Raghavendran, V.; Yakimenko, O.; Persson, G.; Christakopoulos, P. A novel hybrid organosolv: Steam explosion method for the efficient fractionation and pretreatment of birch biomass. Biotechnol. Biofuels 2018, 11, 1-14. [CrossRef] [PubMed]

6. Zhang, J.; Tang, M.; Viikari, L. Xylans inhibit enzymatic hydrolysis of lignocellulosic materials by cellulases. Bioresour. Technol. 2012, 121, 8-12. [CrossRef] [PubMed]

7. Kristensen, J.B.; Thygesen, L.G.; Felby, C.; Jorgensen, H.; Elder, T. Cell wall structural changes in wheat straw pretreated for bioethanol production. Biotechnol. Biofuels 2008, 1, 1-9. [CrossRef]

8. Sipponen, M.H.; Rahikainen, J.; Leskinen, T.; Pihlajaniemi, V.; Mattinen, M.L.; Lange, H. Strutural changes of lignin in biorefinery pretreatments and consequences to enzyme-lignin interactions. Nordic Pulp Pap. Res. J. 2018, 32, 550-571. [CrossRef]

9. Steinbach, D.; Kruse, A.; Sauer, J.; Storz, J. Is Steam Explosion a Promising Pretreatment for Acid Hydrolysis of Lignocellulosic Biomass? Processes 2020, 8, 1626. [CrossRef]

10. Trubetskaya, A.; Lange, H.; Wittgens, B.; Brunsvik, A.; Crestini, C.; Rova, U.; Christakopoulos, P.; Leahy, J; Matsakas, L. Structural and Thermal Characterization of Novel Organosolv Lignins from Wood and Herbaceous Sources. Processes 2020, 8, 860. [CrossRef]

11. Kalogiannis, K.G.; Matsakas, L.; Lappas, A.A.; Rova, U.; Christakopoulos, P. Aromatics from Beechwood Organosolv Lignin through Thermal and Catalytic Pyrolysis. Energies 2019, 12, 1606. [CrossRef]

12. Wyman, C.E.; Dale, B.E.; Elander, R.T.; Holtzapple, M.; Ladisch, M.R.; Lee, Y.Y. Coordinated development of leading biomass pretreatment technologies. Bioresour. Technol. 2005, 96, 1959-1966. [CrossRef]

13. Constant, S.; Wienk, H.L.J.; Frissen, A.E.; de Peinder, P.; Boelens, R.; van Es, D. New insights into the structure and composition of technical lignins: A comparative characterisation study. Green Chem. 2016, 18, 2651-2665. [CrossRef]

14. Penín, L.; Gigli, M.; Sabuzi, F.; Santos, V.; Galloni, P.; Conte, V.; Parajó, J.; Lange, H.; Crestini, C. Biomimetic Vanadate and Molybdate Systems for Oxidative Upgrading of Iono- and Organosolv Hard- and Softwood Lignins. Processes 2020, 8, 1161. [CrossRef]

15. Bhattacharyya, S.; Matsakas, L.; Rova, U.; Christakopoulos, P. Melt Stable Functionalized Organosolv and Kraft Lignin Thermoplastic. Processes 2020, 8, 1108. [CrossRef]

16. Kongkeitkajorn, M.; Sae-Kuay, C.; Reungsang, A. Evaluation of Napier Grass for Bioethanol Production through a Fermentation Process. Processes 2020, 8, 567. [CrossRef]

17. Patel, A.; Arora, N.; Sartaj, K.; Pruthi, V.; Pruthi, P.A. Sustainable biodiesel production from oleaginous yeasts utilizing hydrolysates of various non-edible lignocellulosic biomasses. Renew. Sustain. Energy Rev. 2016, 62, 836-855. [CrossRef]

18. Patel, A.; Mikes, F.; Bühler, S.; Matsakas, L. Valorization of brewers' spent grain for the production of lipids by oleaginous yeast. Molecules 2018, 23, 3052. [CrossRef] [PubMed]

19. Xenopoulos, E.; Giannikakis, I.; Chatzifragkou, A.; Koutinas, A.; Papanikolaou, S. Lipid Production by Yeasts Growing on Commercial Xylose in Submerged Cultures with Process Water Being Partially Replaced by Olive Mill Wastewaters. Processes 2020, 8, 819. [CrossRef]

20. Trubetskaya, A.; Johnson, R.; Monaghan, R.F.D.; Ramos, A.S.; Brunsvik, A.; Wittgens, B.; Han, Y.; Pisano, I.; Leahy, J.J; Budarin, V. Combined analytical strategies for chemical and physical characterization of tar from torrefaction of olive stone. Fuel 2021, 291, 120086. [CrossRef]

21. Charis, G.; Danha, G.; Muzenda, E. Optimizing Yield and Quality of Bio-Oil: A Comparative Study of Acacia tortilis and Pine Dust. Processes 2020, 8, 551. [CrossRef] 
22. Fassio, F.; Tecco, N. Circular Economy for Food: A Systemic Interpretation of 40 Case Histories in the Food System in Their Relationships with SDGs. Systems 2019, 7, 43. [CrossRef]

23. Surup, G.; Trubetskaya, A.; Tangstad, M. Life Cycle Assessment of Renewable Reductants in the Ferromanganese Alloy Production: A Review. Processes 2021, 9, 185. [CrossRef]

24. Surup, G.; Trubetskaya, A.; Tangstad, M. Charcoal as an Alternative Reductant in Ferroalloy Production: A Review. Processes 2020, 8, 1432. [CrossRef]

25. Surup, G.; Pedersen, T.; Chaldien, A.; Beukes, J.; Tangstad, M. Electrical Resistivity of Carbonaceous Bed Material at High Temperature. Processes 2020, 8, 933. [CrossRef] 